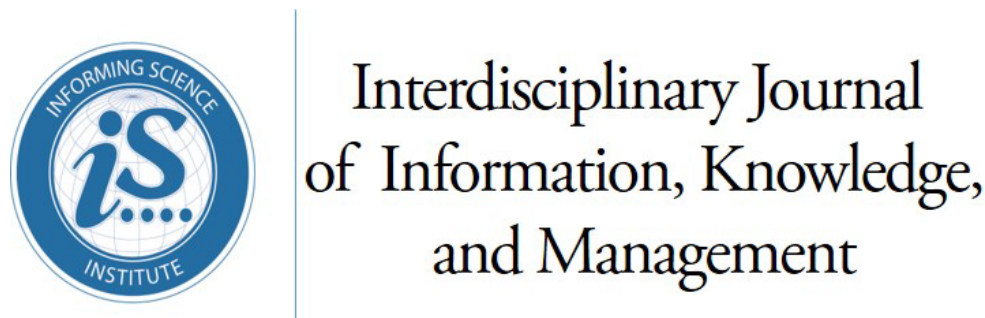

An Official Publication

of the Informing Science Institute

InformingScience.org

IJIKM.org

\title{
Volume 12, 2017 \\ THE APPLiCATION OF A KNOWLEDGE MANAGEMENT FRAMEWORK TO AUTOMOTIVE ORIGINAL COMPONENT MANUFACTURERS
}

André P. Calitz*

Margaret Cullen

* Corresponding author

\author{
Department of Computing Sciences \\ Nelson Mandela University \\ Port Elizabeth, South Africa \\ Business School \\ Nelson Mandela University \\ Port Elizabeth, South Africa
}

Andre.Calitz@,Mandela.ac.za

Margaret.Cullen@,Mandela.ac.za

\section{ABSTRACT}

\begin{abstract}
Aim/Purpose This paper aims to present an example of the application of a Knowledge Management (KM) framework to automotive original component manufacturers (OEMs). The objective is to explore KM according to the four pillars of a selected KM framework.

Background This research demonstrates how a framework, namely the George Washington University's Four Pillar Framework, can be used to determine the KM status of the automotive OEM industry, where knowledge is complex and can influence the complexity of the KM system (KMS) used.

Methodology An empirical study was undertaken using a questionnaire to gather quantitative data. There were 38 respondents from the National Association of Automotive Component and Allied Manufacturers (NAACAM) and suppliers from three major automotive OEMs. The respondents were required to be familiar with the company's KMS.

Contribution Currently there is a limited body of research available on the KM implementation frameworks for the automotive industry. This study presents a novel approach to the use of a KM framework to reveal the status of KM in automotive OEMs. At the time of writing, the relationship between the four pillars and the complexity of KMS had not yet been determined.

Findings The results indicate that there is a need to improve KM in the automotive OEM industry. According to the relationships investigated, the four pillars, namely leadership, organization, technology and learning, are considered important for KM, regardless of the level of KMS complexity,
\end{abstract}

Accepted by Editor Tharrenos Bratitsis | Received: August 14, 2017 | Revised: November 9, November 27, 2017 | Accepted: December 4, 2017.

Cite as: Calitz, A. P., \& Cullen, M. (2017). The application of a knowledge management framework to automotive original component manufacturers. Interdisciplinary Journal of Information, Knowledge, and Management, 12, 337365. https://doi.org/10.28945/3897

(CC BY-NC 4.0) This article is licensed to you under a Creative Commons Attribution-NonCommercial 4.0 International License. When you copy and redistribute this paper in full or in part, you need to provide proper attribution to it to ensure that others can later locate this work (and to ensure that others do not accuse you of plagiarism). You may (and we encourage you to) adapt, remix, transform, and build upon the material for any non-commercial purposes. This license does not permit you to use this material for commercial purposes. 
Recommendations Automotive OEMs need to ensure that the KM aspects are established and should for Practitioners be periodically evaluated by using a KM framework such as the George Washington University's Four Pillar Framework to identify KM weaknesses.

Recommendation The establishment and upkeep of a successful KM environment is challenging due for Researchers to the complexity involved with various influencing aspects. To ensure that all aspects are considered in KM environments, comprehensive KM frameworks, such as the George Washington University's Four Pillar Framework, need to be applied.

Impact on Society The status of KM management and accessibility of knowledge in organizations needs to be periodically examined, in order to improve supplier and OEM knowledge sharing.

Future Research Although the framework used provides a process for KM status determination, this study could be extended by investigating a methodology that includes KMS best practice and tools. This study could be repeated at a national and international level to provide an indication of KM practice within the entire automotive industry.

Keywords knowledge management, knowledge management system, framework, automotive industry

\section{INTRODUCTION}

The global automotive industry is a significant contributor to the global economy and the well-being of the world's citizens. Sales are expected to climb to 17.8mn units in 2017 (Scotiabank, 2017). This is a significant growth since the 2005 figures of producing a total of 66 million cars, vans, trucks and busses, which is the equivalent to a global turnover of $€ 2$ trillion (OICA, 2011). It is estimated that each direct job in the automotive industry supports at least five indirect jobs in the global community, resulting in more than 50 million jobs. Growth in vehicle sales internationally has stabilised considerably and global growth is expected to improve from 3.0\% in 2016 to 3.4\% in 2017 (Scotiabank, 2017). In contrast, for the third year in succession in South Africa, new vehicle sales during 2016 recorded a year on year decline (NAAMSA, 2017). Similar trends are experienced in countries such as Canada and Mexico, where vehicle sales are expected to decrease in 2017 (Scotiabank, 2017).

Global integration has proceeded the furthest at the level of buyer-supplier relationships, especially between automotive manufacturers and their largest suppliers (Sturgeon \& Van Biesebroeck, 2010). Sturgeon and Van Biesebroeck (2010) state that the close collaboration and co-location of Original Equipment Manufacturers (OEMs) and their suppliers that have always characterised the industry, is finally working to the advantage of developing countries. The automotive industry is widely viewed to be the second biggest employer in South Africa, behind mining. Thus, the South African government has made the automotive industry a priority through various policy adjustments. The Eastern Cape Province in South Africa plays a vital role in the South African economy as it is considered the "Detroit of South Africa." Promoted by its Industrial Development Zones (IDZs), the Eastern Cape Province is a favourable location for investment by automotive manufacturers (ECDC, 2011).

However, in South Africa, as in many other automotive-producing countries, knowledge loss has been occurring due to the phenomenon of the "brain drain", which refers to the result of the retirement of experienced professionals, the changing work behaviours among the younger generations and the general lack of new talent infusion into the South African automotive industry over the past decade (Liebowitz, 1999). Internationally, top talent is not abandoning the automotive industry but employees are migrating to the innovators in the car market, specifically the manufacturers of selfdriving and electric cars (Gifford, 2015). Companies have found that the investment in employees through training, by formal and informal knowledge transfer, is lost when these individuals resign. This leads to the loss of organizational knowledge and contributes to errors, duplication of work and additional investment needed for the training and development of replacement employees. Knowledge loss has also been eminent in relationships between buyers and sellers, pertaining to 
knowledge stickiness, which refers to information that is difficult to transfer (Li, 2012; von Hippel, 1994). This realisation has spawned a growing interest in the concept of Knowledge Management (KM).

Establishing principles for $\mathrm{KM}$ is one of the most effective actions management can take to support a knowledge management program in an organization (Mar, 2013). Knowledge management principles are a set of guidelines for managing knowledge that are established by an organization. Organizations, specifically in the automotive industry need to improve KM. The focus of this research paper is the presentation of a case study on the application of a knowledge management framework to automotive original component manufacturers. A literature review is provided on knowledge management, knowledge management frameworks and specifically the selected four-pillar knowledge management framework and its application to the automotive industry. The research methodology is discussed, followed by the results and a discussion of the results. Finally, conclusions and future research are presented.

\section{KNOWLEDGE MANAGEMENT FRAMEWORKS}

$\mathrm{KM}$ is the planned and continuous management of tools, processes, systems, structures and cultures to improve the creation, sharing and use of knowledge critical for decision-making and competitiveness (Kinicki \& Kreitner, 2008). According to Moore (2012), the most important resource that can be leveraged to create and sustain competitiveness in organizations may be knowledge. MagnierWatanabe and Senoo (2008) in their definition of KM place emphasis on the knowledge value chain (Magnier-Watanabe, 2011). Magnier-Watanabe and Senoo (2008) state that KM is the process of acquiring, storing, sharing, disseminating and applying knowledge both inside and outside the organization, with the goal of efficiently meeting corporate objectives. The effective use of KM helps organizations to improve the quality of their decision-making and thus, to reduce costs and increase efficiency and monitoring capabilities (Ferreira, Faria, Azevedo, \& Marques, 2016; Heisig et al., 2016; Kinicki \& Kreitner, 2008).

Effective KM has a positive effect on organizational innovation, efficiency and profitability (LopezNicolas \& Merono, 2011). In an empirical study, based on 310 Spanish organizations, Lopez-Nicolas and Merono (2011) found that organizations that manage KM strategically, improve the organizational performance and innovation. The research findings indicated that the management of organizations should convince all stakeholders, including suppliers, about the positive impact of KM and KM strategy on innovation and organizational performance. Organizations with a clear KM strategy can be more innovative, achieve improved financial results, improve business processes and develop the capabilities of personnel.

Heisig (2009) conducted a study to analyse KM frameworks from research and industry, in terms of KM framework elements as well as similarities and differences. The study concluded that an underlying consensus was evident regarding the basic categories used to describe the knowledge management activities and the critical success factors (CSFs) of KM. The literature investigated by Heisig (2009) yielded various KM frameworks and models, including the following, as discussed and listed by Holsapple and Joshi (1999):

- Framework of Knowledge Management Pillars;

- Framework of Core Capabilities and Knowledge Building;

- Model of Organizational Knowledge Management;

- Framework of the Knowledge Organization; and

- Framework of Knowledge Management Stages.

However, Holsapple and Joshi (1999), conclude that none of the earlier frameworks subsume the others and that there is a need for a framework with a standardised way of characterising the influences on the application of KM. A more recent framework developed and refined by the George 
Washington University between May 2000 and May 2004, namely the "Four Pillars of Knowledge Management" framework, builds on the work of earlier researchers (Stankosky, 2005) and has been identified as an appropriate outline upon which to base this study.

The Four Pillars of Knowledge Management framework involves four environmental influences, which are: Social, Political, Governmental and Economic (Figure 1). The four pillars of the framework are: Leadership, Organization, Technology and Learning. These four pillars are domains that have continuously shown the potential to encompass all aspects of effective knowledge sharing and collaborative cultures (Stankosky, Calabrese, \& Baldanza, 2003). Leadership deals with decisionmaking and the strategic alignment of KM initiatives with business objectives. The pillar related to Organization emphasises the strategic redesigning and alignment of operational processes and procedures to ensure the success of the KM initiative throughout the organization. The Technology pillar establishes the importance of the enabling technological infrastructure, which supports KM within the organization and without which the application of KM in any organization would be near impossible. Finally, Learning, in this context, is described as the acquisition of knowledge or a skill through study, experience or instruction and emphasises the fact that the organization must address $\mathrm{KM}$ facilitating approaches such as increasing internal communications, promoting cross-functional teams and creating a learning community. This study focuses on the four pillars of the framework, which may be manipulated by management to enhance organizational performance through KM.

\section{Four pillars of knowledge management.}

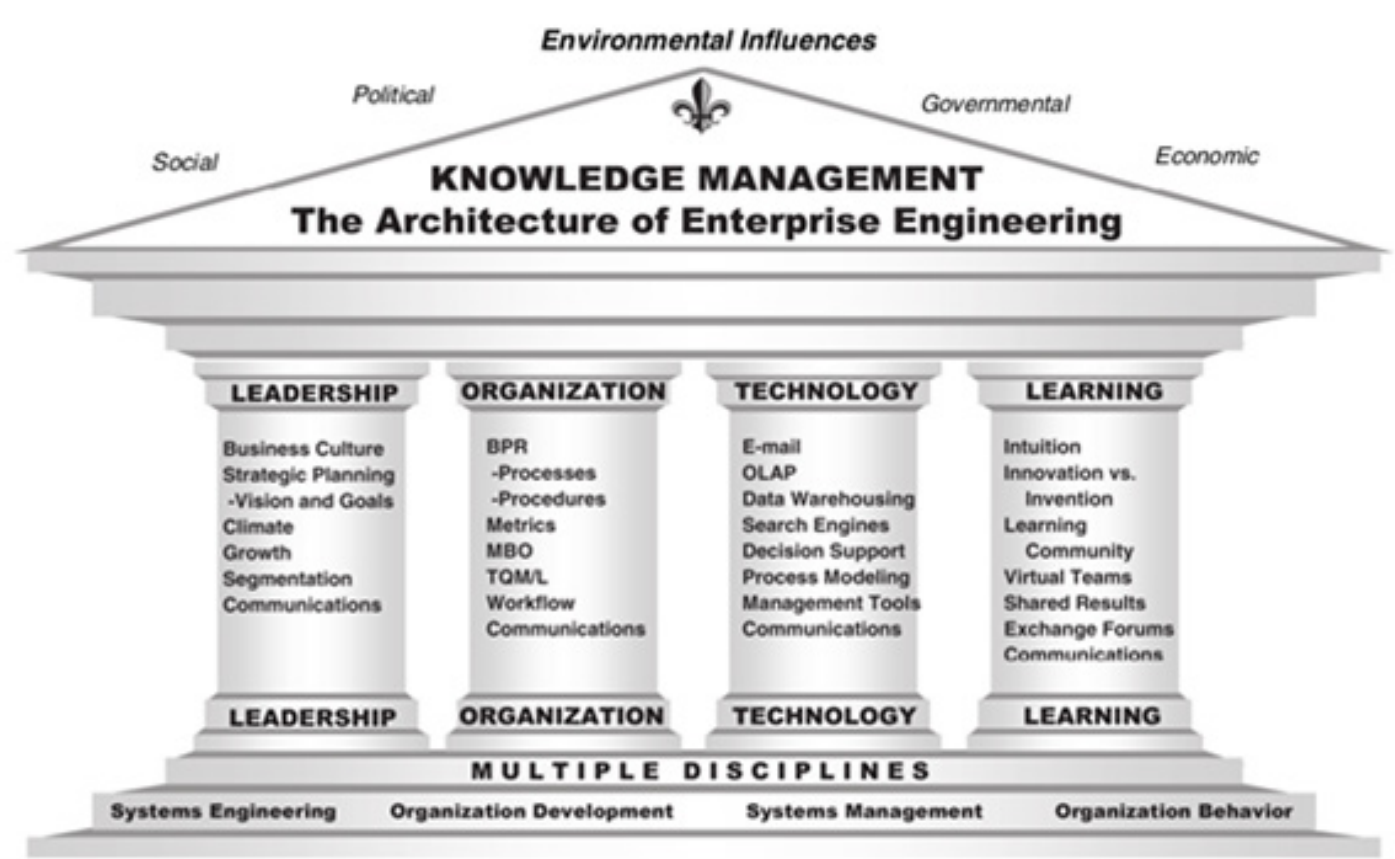

Figure 1. Four Pillars of Knowledge Management (Stankosky, Calabrese, \& Baldanza, 2003)

Most automotive OEMs have made some attempt at KM initiatives (Piderit, 2007). However, among the automotive component suppliers, limited evidence exists of attempts at KM. A literature review of available sources on frameworks for the automotive industry has confirmed, as stated by Piderit (2007, p.59), that there is a very limited body of research available on KM implementation frameworks for the automotive industry. In the South African automotive industry, KM appears to be more prevalent in the large and extra-large multinational OEM companies where the necessary resources are available. These include BMW, Mercedes-Benz, Ford, General Motors, Toyota and Volkswagen (Calitz \& Calitz, 2002; Piderit, 2007). Most of these multinational automotive OEMs have developed a Knowledge Management System (KMS) which complements the organization's 
culture and is context-specific, which is a key success factor of KM (Calitz \& Calitz, 2002; Keshavarz, Heydari, \& Farsijani, 2015; Piderit, 2007).

According to Becerra-Fernandez and Sabherwal (2015), a KMS is the integration of technologies and mechanisms that are designed to support the activities of KM. There are four types of KMS. A knowledge discovery system synthesises prior knowledge or supports the process of developing new tacit or explicit knowledge. Knowledge capture systems assist in the process of retrieving tacit or explicit knowledge that could exist in various locations. A knowledge sharing system supports the process of communicating knowledge to other individuals. Lastly, knowledge application systems assist in the process of using knowledge held by other individuals without having to learn that knowledge. Due to the increasing complexity of underlying knowledge domains, such as in the automotive OEM industry, KMS needs to be able to support the level of complexity. This level of complexity can also be referred to as context complexity (Ozlen, Handzic, \& Durmic, 2014) but for the purposes of this study, it will be referred to as KMS complexity. KMS complexity can increase, depending on the level on which KM is practised, which can be:

1. not practised at all;

2. practised internally only;

3. practised internally and with OEM customers;

4. practised internally and with other suppliers; or

5. practised internally and with OEM customers and other suppliers.

Literature studies regarding $\mathrm{KM}$ in the automotive industry have focused on the connection between KM practices and organizational performance (Sawant, Teli, \& Gaikwad, 2015). In a study in the automotive sector, Sawant, et al. (2015) found that suppliers who are involved in the manufacturing process improve product performance and the use of $\mathrm{KM}$ tools improves the financial performance of an organization. A supplier-oriented KM model is proposed by Sawant, et al. (2015). This alludes to the possibility that many of the $1^{\text {st }}$ tier OEMs in the automotive industry may not be applying KM due to a lack of resources available to manage complex information technology (IT) infrastructures. At the time of writing this paper, no study existed which applied a KMS framework to indicate KMS complexity at automotive component manufacturers within the Eastern Cape Province. The following research problem will therefore be addressed in this research study:

"No standard Knowledge Management Framework, has been applied to automotive component manufacturers to indicate KMS complexity."

A suitable framework is therefore required to enable practitioners to understand KMS complexity by ensuring that the correct KM Aspects are pursued and thereby enhance the quality of decisionmaking, focusing actions and avoiding costly, wasted efforts.

\section{THE APPliCATION OF A KNOWLEDGE MANAGEMENT FRAMEWORK IN THE AUTOMOTIVE INDUSTRY}

The literature investigation revealed aspects of KMS complexity in the automotive industry within the Eastern Cape Province. The CSFs required for KM, as outlined by Baloh and Desouza (2009) and Skyrme (1997) have been compared to the Socio-Technical KMS established by Sajeva and Jucevicius (2010) to identify areas of commonality. The areas have been synthesised to derive a common list of $K M$ Aspects, comprising areas derived from all three authors and a designated label has been assigned to each aspect (Table 1). The ten aspects relate to leadership (strategic leadership and management), organization (organization learning, KM and infrastructure) and technology and learning. The alignment of the KM strategy to the business strategy is specifically highlighted by Baloh and Desouza (2009) and KM governance structures and processes are explained in detail by Sajeva and Jucevicius (2010). 
Table 1. Merged KM aspects

\begin{tabular}{|c|c|c|c|}
\hline $\begin{array}{l}\text { Baloh and Desouza } \\
\text { (2009) }\end{array}$ & Skyrme (1997) & $\begin{array}{l}\text { Sajeva and Jucevicius } \\
(2010)\end{array}$ & $\begin{array}{l}\text { Designated } \\
\text { Label of KM } \\
\text { Aspect }\end{array}$ \\
\hline \multirow[b]{2}{*}{$\begin{array}{l}\text { Clear KM vision and } \\
\text { strategy }\end{array}$} & $\begin{array}{l}\text { A compelling vision and architecture - } \\
\text { frameworks that drive the agenda for- } \\
\text { ward }\end{array}$ & \multirow[b]{2}{*}{ Strategic Leadership } & \multirow[b]{2}{*}{$\begin{array}{l}\text { Strategic } \\
\text { Leadership }\end{array}$} \\
\hline & $\begin{array}{l}\text { A knowledge leader or champion - } \\
\text { someone who actively drives the } \\
\text { knowledge agenda forward, creates } \\
\text { enthusiasm and commitment (for ex- } \\
\text { ample, a Chief Knowledge Officer) }\end{array}$ & & \\
\hline $\begin{array}{l}\text { Alignment of KM } \\
\text { strategy to business } \\
\text { goals }\end{array}$ & & & $\begin{array}{l}\text { Alignment of } \\
\text { KM strategy to } \\
\text { business goals }\end{array}$ \\
\hline $\begin{array}{l}\text { Promoting a learning } \\
\text { culture }\end{array}$ & & Organizational learning & \multirow{2}{*}{$\begin{array}{l}\text { Organizational } \\
\text { learning }\end{array}$} \\
\hline $\begin{array}{l}\text { A positive attitude to } \\
\text { knowledge sharing }\end{array}$ & & Knowledge culture & \\
\hline $\begin{array}{l}\text { Incentives for } \\
\text { knowledge creation } \\
\text { and reuse }\end{array}$ & $\begin{array}{l}\text { A clear value proposition- identifica- } \\
\text { tion of the link between knowledge } \\
\text { and the bottom line business benefit; } \\
\text { new measures of performance and } \\
\text { appropriate rewards }\end{array}$ & & $\begin{array}{l}\text { Value } \\
\text { proposition }\end{array}$ \\
\hline $\begin{array}{l}\text { A community that } \\
\text { provides a context for } \\
\text { KM to flourish }\end{array}$ & & & $\begin{array}{l}\text { Organizational } \\
\text { KM context }\end{array}$ \\
\hline $\begin{array}{l}\text { Continuous top man- } \\
\text { agement support }\end{array}$ & $\begin{array}{l}\text { Top management support - a CEO } \\
\text { who recognises the value of } \\
\text { knowledge and who actively supports } \\
\text { the knowledge team in its work }\end{array}$ & & $\begin{array}{l}\text { Top } \\
\text { management } \\
\text { support }\end{array}$ \\
\hline $\begin{array}{l}\text { Employee empower- } \\
\text { ment }\end{array}$ & & & $\begin{array}{l}\text { Employee } \\
\text { empowerment }\end{array}$ \\
\hline $\begin{array}{l}\text { A flexible organiza- } \\
\text { tion structure }\end{array}$ & & $\begin{array}{l}\text { Organizational infrastruc- } \\
\text { ture }\end{array}$ & $\begin{array}{l}\text { Organizational } \\
\text { infrastructure }\end{array}$ \\
\hline $\begin{array}{l}\text { Usable and up-to-date } \\
\text { KMS }\end{array}$ & & $\begin{array}{l}\text { Technological Infrastruc- } \\
\text { ture }\end{array}$ & $\begin{array}{l}\text { Technological } \\
\text { Infrastructure }\end{array}$ \\
\hline \multirow{6}{*}{$\begin{array}{l}\text { Knowledge govern- } \\
\text { ance structure for } \\
\text { maintaining quality of } \\
\text { knowledge content }\end{array}$} & \multirow{6}{*}{$\begin{array}{l}\text { Effective information and knowledge } \\
\text { management processes }\end{array}$} & Knowledge identification & \multirow{6}{*}{$\begin{array}{l}\text { KM } \\
\text { governance } \\
\text { structure and } \\
\text { process }\end{array}$} \\
\hline & & Knowledge acquisition & \\
\hline & & Knowledge creation & \\
\hline & & Knowledge storage & \\
\hline & & Knowledge dissemination & \\
\hline & & Knowledge application & \\
\hline
\end{tabular}

Calabrese and Orlando (2006) proposed a 12-step process, which was logically classified according to the four pillars of the George Washington University's Four Pillar Framework (Table 2). The 12-step process provides a broad outline of the various aspects of applying $\mathrm{KM}$ in organizations and serves as a useful process that can be used to map KM activities to the four pillars. To align the merged KM Aspects (Table 1) with the four pillars of the George Washington University's Four Pillar Framework, namely: Leadership, Organization, Technology and Learning, the merged KM Aspects have been mapped to Calabrese and Orlando's (2006) 12-step process (Table 2). The Selected KM Framework 
(Table 3) has been derived from the existing body of literature and presents the merged listing of KM Aspects, which are compared with Calabrese and Orlando's (2006) 12-step framework.

Table 2. KM 12-step process (Calabrese \& Orlando, 2006)

\begin{tabular}{|l|c|l|}
\hline Pillar & Steps & 12-step process \\
\hline \multirow{3}{*}{ Leadership } & 1 & Identify knowledge critical to your business \\
\cline { 2 - 3 } & 2 & Conduct work-centred analysis \\
\cline { 2 - 3 } & 3 & Sell high-level plan of action to senior management \\
\hline \multirow{4}{*}{ Organization } & 4 & Engage key stakeholders \\
\cline { 2 - 3 } & 5 & Develop process model \\
\cline { 2 - 3 } & 6 & Identify critical knowledge gaps, opportunities and risks \\
\cline { 2 - 3 } & 7 & Establish and prioritise goals \\
\hline \multirow{3}{*}{ Technology } & 8 & Develop requirements and measurement programme \\
\cline { 2 - 3 } & 9 & Plan high-level strategy approach \\
\cline { 2 - 3 } & 10 & Implement strategy, build and deploy \\
\hline Learning & 11 & Monitor, measure, and report metrics \\
\hline
\end{tabular}

Table 3. Selected KM application framework

\begin{tabular}{|c|c|c|c|c|c|c|c|c|c|c|c|c|}
\hline & Lead & ershi & & Org & aniz: & ation & & & Tech & nology & & $\begin{array}{l}\text { Learn- } \\
\text { ing }\end{array}$ \\
\hline & 1 & 2 & 3 & 4 & 5 & 6 & 7 & 8 & 9 & 10 & 11 & 12 \\
\hline KM Aspect & 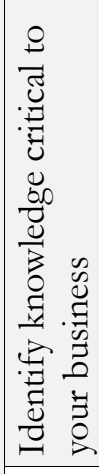 & 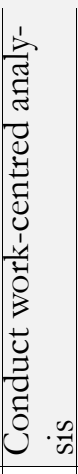 & 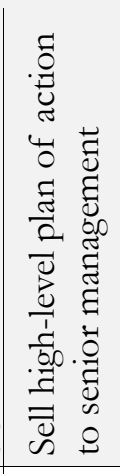 & 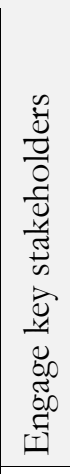 & 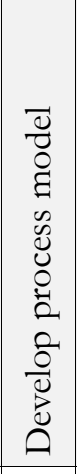 & 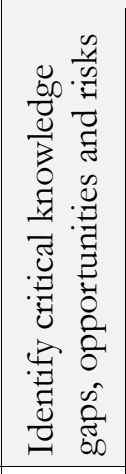 & 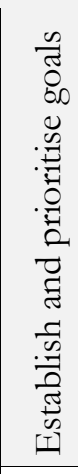 & 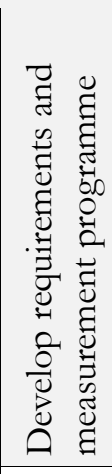 & 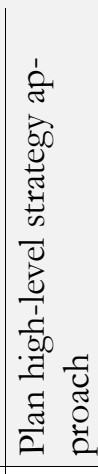 & 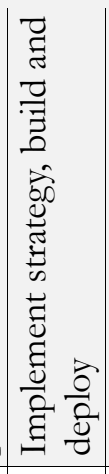 & 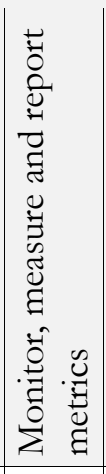 & 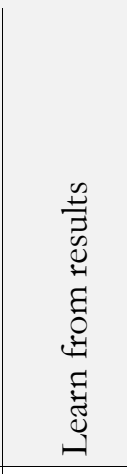 \\
\hline $\begin{array}{l}\text { Strategic } \\
\text { leadership }\end{array}$ & $\checkmark$ & & $\checkmark$ & $\checkmark$ & $\checkmark$ & $\checkmark$ & $\checkmark$ & $\checkmark$ & $\checkmark$ & & & $\checkmark$ \\
\hline $\begin{array}{l}\text { Alignment of } \\
\text { KM strategy to } \\
\text { business goals }\end{array}$ & $\checkmark$ & $\checkmark$ & & $\checkmark$ & $\checkmark$ & $\checkmark$ & $\checkmark$ & & $\checkmark$ & & & \\
\hline $\begin{array}{l}\text { Organizational } \\
\text { learning }\end{array}$ & $\checkmark$ & & & $\checkmark$ & & $\checkmark$ & & & & & & $\checkmark$ \\
\hline $\begin{array}{l}\text { Value } \\
\text { proposition }\end{array}$ & & & $\checkmark$ & $\checkmark$ & & $\checkmark$ & $\checkmark$ & & & & & \\
\hline $\begin{array}{l}\text { Organizational } \\
\text { KM context }\end{array}$ & & & & $\checkmark$ & & $\checkmark$ & & & & & $\checkmark$ & \\
\hline $\begin{array}{l}\text { Top manage- } \\
\text { ment support }\end{array}$ & $\checkmark$ & $\checkmark$ & & & & & & & & & & \\
\hline
\end{tabular}




\begin{tabular}{|c|c|c|c|c|c|c|c|c|c|c|c|c|}
\hline & Lead & ershi & & Org & aniz & ation & & & Techn & nology & & $\begin{array}{l}\text { Learn- } \\
\text { ing }\end{array}$ \\
\hline & $\mid 1$ & 2 & 3 & 4 & 5 & 6 & 7 & 8 & 9 & & 11 & 12 \\
\hline KM Aspect & 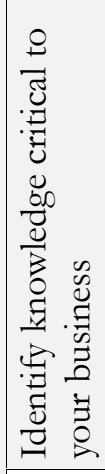 & 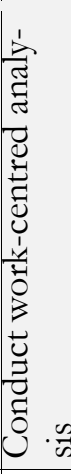 & 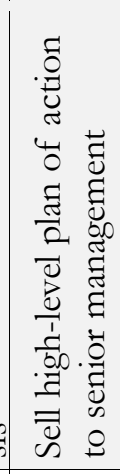 & 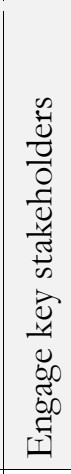 & 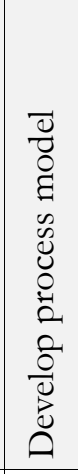 & 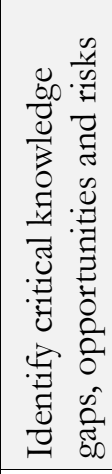 & 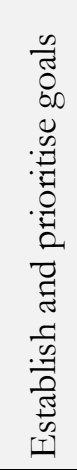 & 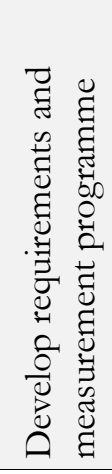 & 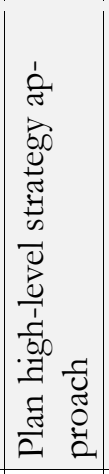 & 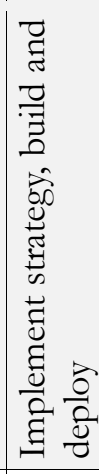 & 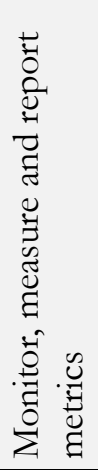 & 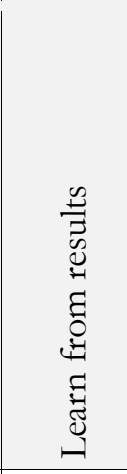 \\
\hline $\begin{array}{l}\text { Employee } \\
\text { empowerment }\end{array}$ & $\checkmark$ & $\checkmark$ & & $\checkmark$ & & $\checkmark$ & $\checkmark$ & $\checkmark$ & $\checkmark$ & & & $\checkmark$ \\
\hline $\begin{array}{l}\text { Organizational } \\
\text { infrastructure }\end{array}$ & & & & $\checkmark$ & $\checkmark$ & $\checkmark$ & $\checkmark$ & $\checkmark$ & $\checkmark$ & & & \\
\hline $\begin{array}{l}\text { Technological } \\
\text { infrastructure }\end{array}$ & & $\checkmark$ & $\checkmark$ & $\checkmark$ & $\checkmark$ & $\checkmark$ & $\checkmark$ & $\checkmark$ & $\checkmark$ & $\checkmark$ & $\checkmark$ & $\checkmark$ \\
\hline $\begin{array}{l}\text { KM governance } \\
\text { structure and } \\
\text { process }\end{array}$ & $\checkmark$ & & & & $\checkmark$ & $\checkmark$ & $\checkmark$ & $\checkmark$ & $\checkmark$ & & $\checkmark$ & \\
\hline
\end{tabular}

A KM Framework was selected for the application of KM in the automotive industry in the Eastern Cape Province (Table 4), which is a simplified version of the alignment of the merged KM Aspects with the four pillars of the George Washington University's Four Pillar Framework (Table 3).

Table 4. Alignment of KM aspects with Four Pillars

\begin{tabular}{|l|c|c|c|c|}
\hline KM Aspect & Leadership & Organization & Technology & Learning \\
\hline Strategic leadership & $\checkmark$ & $\checkmark$ & $\checkmark$ & $\checkmark$ \\
\hline $\begin{array}{l}\text { Alignment of KM strategy to busi- } \\
\text { ness goals }\end{array}$ & $\checkmark$ & $\checkmark$ & $\checkmark$ & \\
\hline Organizational learning & $\checkmark$ & $\checkmark$ & & $\checkmark$ \\
\hline Value proposition & $\checkmark$ & $\checkmark$ & & \\
\hline Organizational KM context & & $\checkmark$ & $\checkmark$ & \\
\hline Top management support & $\checkmark$ & & & \\
\hline Employee empowerment & $\checkmark$ & $\checkmark$ & $\checkmark$ & $\checkmark$ \\
\hline Organizational infrastructure & & $\checkmark$ & $\checkmark$ & \\
\hline Technological infrastructure & $\checkmark$ & $\checkmark$ & $\checkmark$ & $\checkmark$ \\
\hline $\begin{array}{l}\text { KM governance structure and } \\
\text { process }\end{array}$ & & $\checkmark$ & $\checkmark$ & \\
\hline
\end{tabular}




\section{RESEARCH METHODOLOGY}

The objective of this paper is to explore the extent to which KM is being managed in an automotive OEM context, using a KM framework. An in-depth literature review of KM frameworks was undertaken. The literature revealed that the Four Pillars of Knowledge Management encompassed earlier KM frameworks and would be appropriate to use for the purpose of this study. The four pillars of the framework were used to formulate a questionnaire, which was distributed to the automotive industry suppliers and OEMs.

\section{PARTICIPANTS}

Parameters of interest for this study were individuals who were actively involved in the company's KM. The input of sales managers, commercial managers and other personnel of first tier automotive OEMs who played roles in KM environments were therefore acquired. The population of 120 first tier suppliers to OEMs in the Eastern Cape Province of South Africa was established by combining the lists of automotive OEMs for the Eastern Cape Province procured from the National Association of Automotive Component and Allied Manufacturers (NAACAM, 2011) and lists of approved suppliers from the three major automotive OEMs. The three automotive manufacturers in the region were Volkswagen, General Motors and Mercedes-Benz. The 120 OEM suppliers and three automotive manufacturers were contacted individually by telephone to request their participation in the study and to identify the contact person at the company to whom the questionnaire should be sent. A total of 72 potential respondents agreed to participate in the study. The questionnaire was sent electronically by means of an e-mail to the 72 potential respondents and they were reminded to respond on three occasions, after which a total of 38 respondents returned the completed questionnaires.

\section{HYPOTHESIS FORMULATION}

A hypothesised model, based on the literature review, was developed for this research paper (Figure 2). The KM framework was used to establish relationships between the dependent variable, namely the level of KMS complexity and the independent variables: Leadership, Organization, Technology and Learning, which were derived from the four pillars of the George Washington University's Four Pillar Framework. The hypotheses developed in this research study were formulated to be judged true or false by means of statistical analysis through empirical evaluation and to verify the proposed relationships indicated in the hypothesised model.

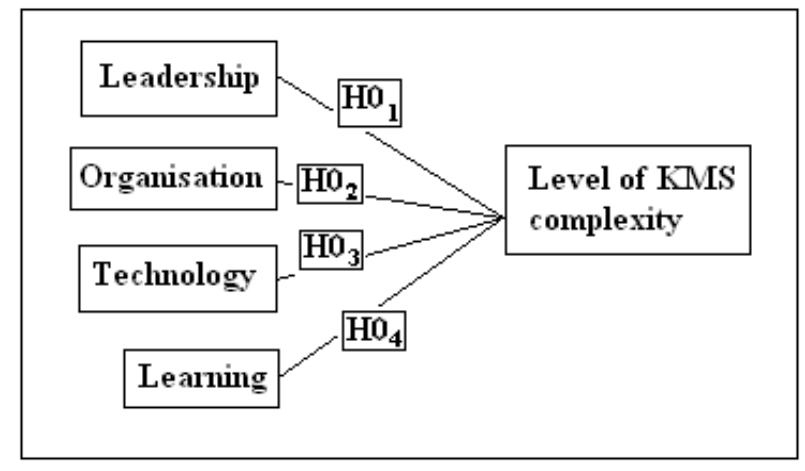

Figure 2. Hypothesised model

The following Null hypotheses were formulated to test the relationship between the dependent variable, Level of KMS complexity and the four independent variables, Leadership, Organization, Technology and Learning:

$\mathbf{H O}_{1}$ : "There is no relationship between Leadership and the level of complexity of the knowledge management system". 
The Application of a KM Framework to Automotive OEMs

$\mathbf{H O}_{2}$ : "There is no relationship between Organization and the level of complexity of the knowledge management system".

$\mathbf{H O}_{3}:$ "There is no relationship between Technology and the level of complexity of the knowledge management system".

HO4: "There is no relationship between Learning and the level of complexity of the knowledge management system".

\section{RESEARCH MATERIALS}

To meet the objectives of this study, a questionnaire was distributed to collect data that would determine the status of automotive OEMs' KM in the Eastern Cape Province (Appendix A). The items in the questionnaire used to measure the status of $\mathrm{KM}$ had five-point semantic differential scales where there were opposing levels such as strongly disagree and strongly agree. The questionnaire items were formulated based on the existing questions from questionnaires of previous research on the subject and were linked to the pillars in the KM framework (Table 5). Linking the questionnaire items to the KM framework was accomplished by considering the $\mathrm{KM}$ aspects regarding the four pillars, namely: leadership, organization, technology and learning and correlating the questions to the relevant KM aspect and pillar. For example, the KM aspect of strategic leadership was linked to the pillar of leadership linking Questions $7 \mathrm{~d}$ and 71 in the questionnaire to this aspect and pillar (Table 5).

Table 5. Questionnaire in relation to the Applied KM Framework

\begin{tabular}{|l|c|c|c|c|}
\hline \multirow{2}{*}{ KM aspect } & \multicolumn{4}{c|}{ GW Four Pillar Framework } \\
\cline { 2 - 5 } & Leadership & Organization & Technology & Learning \\
\hline Strategic Leadership & $7 \mathrm{~d}, \mathrm{l}$ & $9 \mathrm{~d}$ & $13 \mathrm{f}$ & \\
\hline $\begin{array}{l}\text { Alignment of KM strategy to business } \\
\text { goals }\end{array}$ & $7 \mathrm{~d}$ & $7 \mathrm{k}$ & $9 \mathrm{c}$ & \\
\hline Organizational learning & $7 \mathrm{e}, \mathrm{f}, \mathrm{g}$ & $7 \mathrm{~m}$ & & $7 \mathrm{e}, \mathrm{g}, \mathrm{j}, \mathrm{n}, 21$ \\
\hline Value proposition & $7 \mathrm{k}$ & 27 & & \\
\hline Organizational KM context & & $7 \mathrm{f}, \mathrm{g}, 9 \mathrm{a}, \mathrm{e}, \mathrm{f}, \mathrm{g}, \mathrm{h}, \mathrm{i}, \mathrm{j}$ & $13 \mathrm{~d}$ & \\
\hline Top management support & $7 \mathrm{a}$ & & & \\
\hline Employee empowerment & $7 \mathrm{a}, \mathrm{b}$ & $\begin{array}{c}7 \mathrm{~b}, \mathrm{~m}, 9 \mathrm{~d}, \mathrm{f}, \mathrm{g}, \mathrm{h}, \mathrm{i} \\
13 \mathrm{~d}, 21 \mathrm{~m}\end{array}$ & $13 \mathrm{~d}$ & \begin{tabular}{c}
$7 \mathrm{c}, \mathrm{j}, 9 \mathrm{~d}$, \\
\hline Organizational infrastructure
\end{tabular} \\
\hline Technological Infrastructure & $9 \mathrm{c}$ & $9 \mathrm{f}, \mathrm{i}, \mathrm{m}$ \\
\hline KM governance structure and process & & $73 \mathrm{~d}$ & $13 \mathrm{f}$ & $21 \mathrm{f}$ \\
\hline
\end{tabular}

The questionnaire used in this study was constructed from questionnaires used in similar studies. It stated the context of the study for the respondents, by supplying a confidentiality statement, establishing some of the benefits of participating in the study, providing clear instructions for the process of completing the questionnaire and providing a brief list of definitions and explanation of abbreviations that the respondent might not be familiar with. The questionnaire was divided into six sections. Section A provided background information. Section B requested information regarding KM leadership status and Section C contained items related to the description of $\mathrm{KM}$ within the given organization. Section D focused on the technological aspect of KM in the respondent's company. Section $\mathrm{E}$ focused on the status of learning in the KM environment. Section F required respondents to provide information on the challenges in applying KM. 
The reliability of the survey was initially established by conducting a pilot study (Zikmund, 2003). Three senior academics at the Nelson Mandela University (NMU), the NMU consulting statistician and two industry representatives were requested to evaluate the questionnaire and to indicate any issues or lack of clarity of the questionnaire items. Following the pre-testing of the questionnaire, it was then refined and updated in accordance with the input received.

\section{RELIABILITY AND VALIDITY}

Reliability is an indicator of the level of consistency that can be attached to a measurement instrument in its capability to correctly measure the variables under investigation (Collis \& Hussey 2009; Kumar, 2011; Maree, 2012). A measurement is said to be reliable when repeated measurements of an unchanged entity return the same result each time (Leedy \& Omrod 2010). Reliability is vital for positivistic studies. There are two techniques used when measuring reliability namely test and retest reliability. Test reliability is when applying measures of internal consistency; retest reliability is repeating an event to determine if the same or similar results are recorded (Ihantola \& Kihn 2011).

In this study, Cronbach's alpha was used to determine the reliability of the measuring instrument that provided measures of internal consistency reliability. The Cronbach's alpha coefficient was used to measure this internal consistency. A Cronbach's alpha value of between 0.50 and 0.69 is deemed acceptable for new and experimental research (Collis \& Hussey 2009; Nunnally, 1978). In order to contribute to the existing body of knowledge, an important consideration in research conclusions is validity.

In order to describe and summarize the data, descriptive statistics were used. Three types of measures of central tendency were used to describe the data namely the mean, median and mode. This study further tested the relationships between the independent variables, Leadership, Organization, Technology and Learning and the dependent variable Level of KMS complexity.

\section{PROFILE}

Section A of the questionnaire enabled descriptive statistics to be calculated in the form of background information (Table 6). The information collected from respondents was the name of their company, their current position, experience in their current position, time employed at current company, number of employees at their company and a general sense of the status of KM practice at the company.

Table 6. Background information $(n=38)$

\begin{tabular}{|l|l|c|c|}
\hline \multicolumn{2}{|c|}{ Background information } & $\begin{array}{c}\text { Frequency } \\
\text { (n) }\end{array}$ & $\begin{array}{c}\text { Percentage } \\
\text { (\%) }\end{array}$ \\
\hline \multirow{3}{*}{$\begin{array}{l}\text { Tenure in current position } \\
\text { (years) }\end{array}$} & $0-4$ & 19 & 50 \\
\cline { 2 - 4 } & $5-9$ & 5 & 13 \\
\cline { 2 - 4 } & $10-14$ & 8 & 21 \\
\cline { 2 - 4 } & $15-20$ & 2 & 5 \\
\cline { 2 - 4 } & $>20$ & 4 & 11 \\
\hline \multirow{4}{*}{$\begin{array}{l}\text { Length of employment with } \\
\text { company (years) }\end{array}$} & $0-4$ & 10 & 26 \\
\cline { 2 - 4 } & $5-9$ & 5 & 13 \\
\cline { 2 - 4 } & $10-14$ & 9 & 24 \\
\cline { 2 - 4 } & $15-20$ & 5 & 13 \\
\cline { 2 - 4 } & $20+$ & 9 & 24 \\
\hline Company size (people) & $1-49$ & 9 & 24 \\
\cline { 2 - 4 } & $50-249$ & 2 & 24 \\
\cline { 2 - 4 } & $250-499$ & 4 & 5 \\
\cline { 2 - 4 } & $500-1000$ & 9 & 11 \\
\cline { 2 - 4 } & $>1001$ & & 27 \\
\hline
\end{tabular}


The Application of a KM Framework to Automotive OEMs

\begin{tabular}{|l|l|c|c|}
\hline \multicolumn{2}{|c|}{ Background information } & $\begin{array}{c}\text { Frequency } \\
\text { (n) }\end{array}$ & $\begin{array}{c}\text { Percentage } \\
(\%)\end{array}$ \\
\hline \multirow{3}{*}{ KMS level of complexity } & Not practised & 7 & 18 \\
\cline { 2 - 4 } & Internally only & 22 & 58 \\
\cline { 2 - 4 } & $\begin{array}{l}\text { Internally and with OEM cus- } \\
\text { tomers }\end{array}$ & 3 & 8 \\
\cline { 2 - 4 } & $\begin{array}{l}\text { Internally and with other sup- } \\
\text { pliers }\end{array}$ & 3 & 8 \\
\cline { 2 - 4 } & $\begin{array}{l}\text { Internally and with OEM cus- } \\
\text { tomers and other suppliers }\end{array}$ & 3 & 8 \\
\hline
\end{tabular}

The proportion of respondents who have four or less years of experience in their current position is notable. A total of $50 \%(\mathrm{n}=19)$ respondents appear in the category of $0-4$ years' experience and represents a turnover rate for these positions of less than five years, indicating that valuable knowledge is being lost. A total of 10 respondents $(26 \%)$ have not been employed by their organization for more than five years which indicates a relatively high turnover rate. However, the remaining $74 \%$ of respondents $(\mathrm{n}=28)$ are in the categories ranging from 5-9 years to more than 20 years, showing extended tenure with the current organization and therefore retention of tacit knowledge by these organizations. The highest result for the number of people employed at the companies was obtained for the category of 49-250 employees $(36 \%)$. Most respondents $(n=22)$ have the perception that their organization is not practicing KM.

\section{RESULTS}

Cronbach's alpha statistics were used to establish the reliability of the responses to the questionnaire. The observed quantitative data were analyzed to reveal relationships between the four pillars investigated and the level of KMS complexity. When reporting on these results, they will be compared with the literature review findings.

\section{LEADERSHIP}

Cronbach's alpha for this construct was calculated to be 0.91 , indicating high reliability. The mean values of the responses to the questionnaire items related to Leadership show a trend evident in the perceived importance of Leadership across the various levels of KMS complexity (Figure 3). The results show that as KMS complexity increases, so does the level of significance and importance of Leadership, as indicated by the respective mean values:

- Not practised:

mean score $=3.1$

- Internally only:

mean score $=3.8$

- Internally and with others:

mean score $=3.9$

Considering the Null Hypothesis $\mathrm{HO}_{1}$, the p-value, from the Analysis of Variance (ANOVA) test, for Leadership was calculated at $\mathrm{p}=0.01$, indicating that Leadership is "significant" (i.e. $\mathrm{p}<0.05$ ) and that the Null Hypothesis $\left(\mathrm{HO}_{1}\right)$ must be rejected and the Alternative Hypothesis ( $\left.\mathrm{HO}_{1 a l t}\right)$ accepted. The following statement can therefore be made, "There is a relationship between Leadership and the level of complexity of the knowledge management system."

The ANOVA test further revealed that a significant difference in mean values exists between the various levels of KMS complexity. The post hoc test (Tukey's test) indicated that there were significant differences between the group "Not practised" and the other two groups, "Internally only" and "Internally and with others". Between the two groups, "Internally only" and "Internally and with others", however, no significant difference was evident. This finding supports the theory that states that higher levels of Leadership are needed where KM is practised (Stankosky et al., 2003; Skyrme, 1997). 


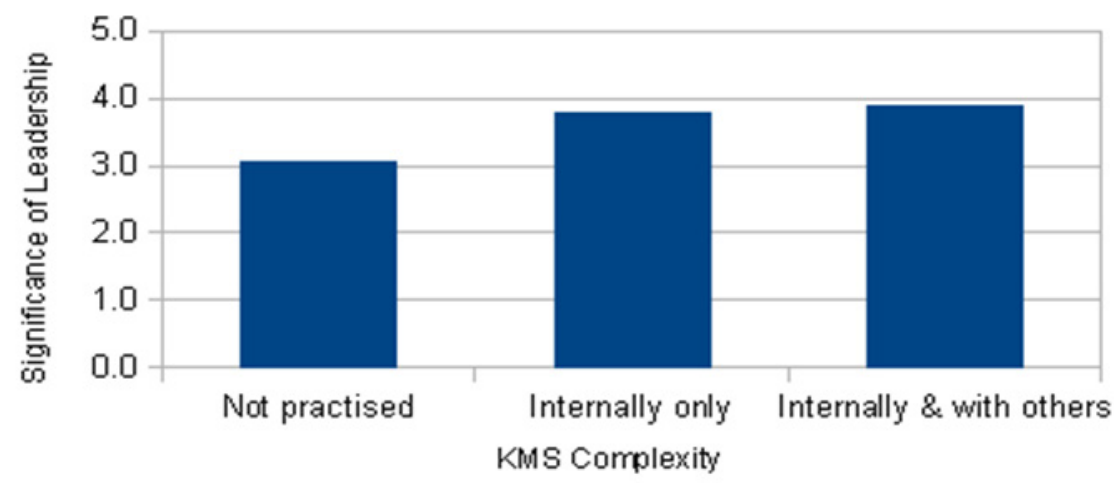

Figure 3. Significance of Leadership $(n=38)$

In small samples, such as the sample investigated in this study, a statistically non-significant result may prove to be of practical importance. This may suggest that there is a real effect, but the sample was too small to detect it. Since analysing the mean values of more than two groups regarding a single quantitative variable is done by using ANOVA, certain statistics that usually form part of the output of such analysis are used in the calculation of an effect size index $\left(\eta^{2}\right)$ known as eta-squared. The index is directly proportional to the size of the differences among the group means and therefore the importance of the difference or relationship. Consequently, a large index will enable "practically significant" results to be obtained.

Steyn (2000) proposes the following guidelines for interpretation of $\left(\eta^{2}\right)$ values:

$\eta^{2} \leq 0.035$

: Small effect size, practical significance, or importance;

$0.035<\eta^{2} \leq 0.100$

: Medium effect size, practical significance, or importance; and

$\eta^{2}>0.100$

: Large effect size, practical significance, or importance.

Calculating eta-squared $\left(\eta^{2}\right)$ for Leadership yielded a value of 0.229 , indicating that this variable has large practical significance. In this case, the correlation between the $\mathrm{p}$-value of $\mathrm{p}=0.01$, shows statistical significance and the eta-squared value of 0.229 indicates large practical significance.

\section{ORGANIZATION}

Statistical analysis of the data for Organization required that the variable be divided into three subcomponents; namely:

- Social networks extending outside of the organization, namely "Soc Netw (Ext)", derived from questions $9 \mathrm{~g}, 9 \mathrm{~h}, 9 \mathrm{i}$ and $9 \mathrm{j}$;

- Organizational infrastructure, namely "Infrastructure", derived from questions 9c and 9d; and

- Social networks existing within the organization, namely "Soc Netw (Int)", derived from questions 9e and 9f.

Cronbach's alpha was calculated for "Soc Netw (Ext)", "Infrastructure", and "Soc Netw (Int)" as $0.77,0.77$ and 0.74 respectively. These values are all above the minimum acceptable cut-off value of 0.7 and indicate that the constructs are reliable. The descriptive statistics clearly indicate a trend when one considers the relative importance of the respective sub-variables, "Soc Netw (Ext)", "Infrastructure" and "Social Netw (Int)" in relation to the three levels of KMS complexity, which are "Not practised", "Internally only" and "Internally and with others" (Figure 4, Figure 5 and Figure 6).

The trend lines in Figures 4, 5 and 6 indicate that the importance of the respective variables (Soc Netw (Ext), Infrastructure and Social Netw (Int)) are perceived to increase as the KMS evolves from the state of Not practised, through Internally only to Internally and with others. Figures 4, 5 and 6 
indicate that the mean scores are positively related to the KMS level of complexity, with the mean scores increasing as KMS complexity level increases.

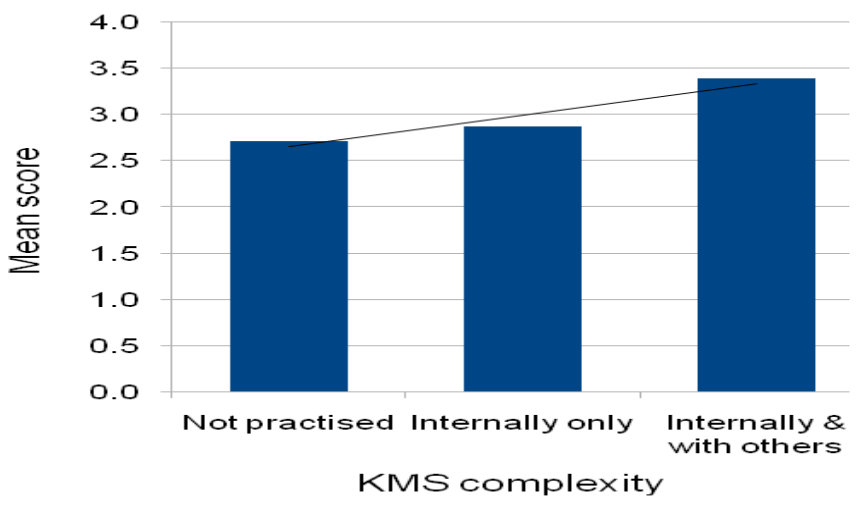

Figure 4. Importance of Soc Netw - Ext $(n=38)$

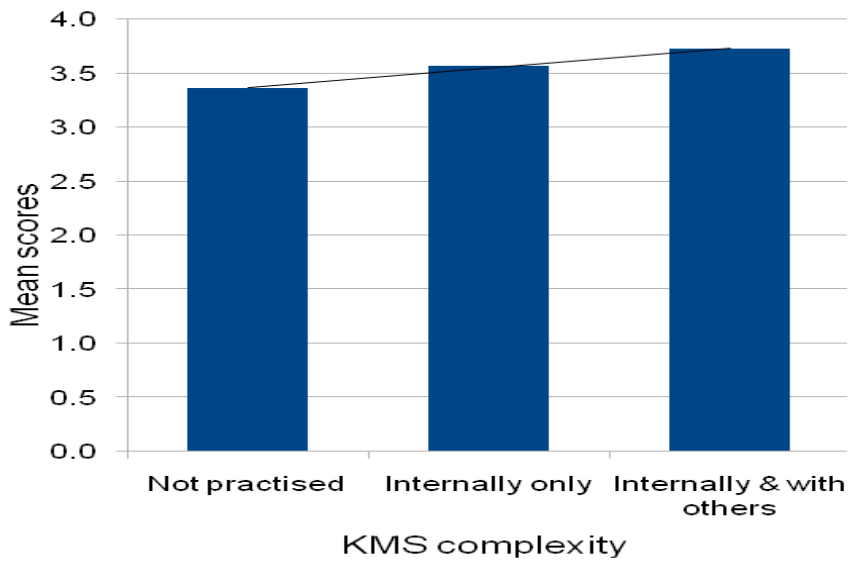

Figure 5. Importance of Infrastructure $(n=38)$

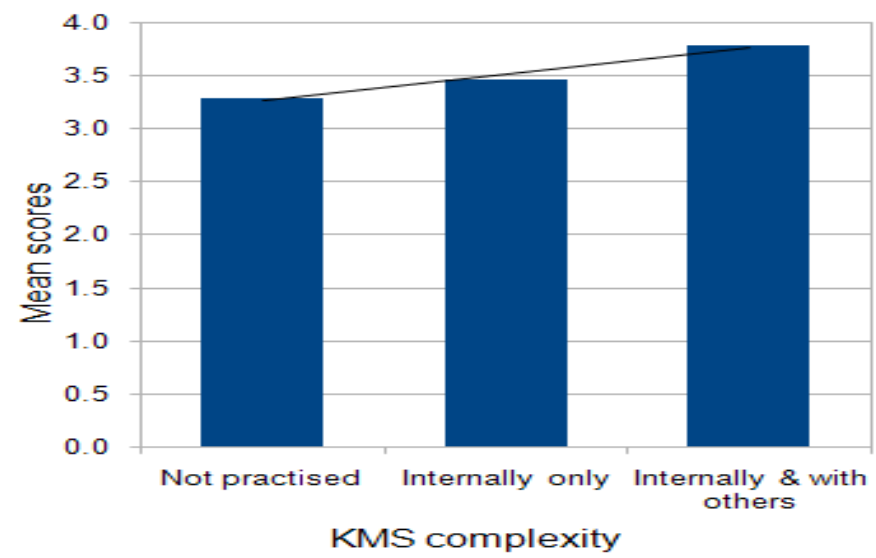

Figure 6. Importance of Soc Netw - Int $(n=38)$

An ANOVA test was used to analyse the differences between the mean values of the three subvariables. The $\mathrm{p}$-values from the ANOVAs for the sub-variables, Soc Netw (Ext) ( $\mathrm{p}=0.11)$, Infrastructure $(\mathrm{p}=0.69)$ and Soc Netw (Int) $(\mathrm{p}=0.31)$ were above the $0.05(95 \%)$ level of significance, indicating 
that these values were not significant and the null hypothesis $\left(\mathrm{H}_{\mathrm{O} 2}\right)$ has not been rejected, which states that "There is no relationship between Organization and the level of complexity of the KMS". Calculating eta-squared $(\eta 2)$ for the sub-variables Soc Netw (Ext), Infrastructure and Soc Netw (Int), yielded the following results:
Soc Netw (Ext)
$\eta 2=0.120$
Large practical significance/importance;
Infrastructure
$\eta 2=0.021$
Small practical significance/importance; and
Soc Netw (Int)
$\eta 2=0.064$
Medium practical significance/importance.

The eta-squared values above indicate that though the Null Hypothesis $\left(\mathrm{H}_{\mathrm{O} 2}\right)$ has not been rejected, which states that, "There is no relationship between Organization and the level of complexity of the knowledge management system", the relationship between Soc Netw (Int) and Soc Netw (Ext) with the level of complexity of the KMS, as measured by the differences in mean scores, is still indicated as having some practical significance.

\section{TECHNOLOGY}

The ranking of the most common technologies as indicated by the responses has been summarised and indicates that at the lower levels of KMS complexity, the technology needs of the organizations differ from those at higher levels of KMS complexity (Table 8). The technologies are listed in order of importance as rated by the number of respondents in each of the three categories. The Internet remains the most important technological tool throughout KMS evolution and complexity. At the lowest level of KMS complexity, namely "Not practised", the Internet is followed by the organization's Intranet, then Data management systems which is followed by E-commerce, Data warehousing, KM software, Extranet, Decision Support System and Automated Manufacturing, which are all ranked at the same level of importance.

At the "Internally only" level of KMS complexity, the Internet, Intranet and data management systems retain their ranking. However, the rating of the technologies that follow are then rearranged as the organization's demands from the system evolve. Table 7 further illustrates that at the final level of KMS complexity, which is "Internally and with others", the Internet is followed, in order of ranking, by Data Management Systems, Intranet, Data Warehousing, KM Software, E-commerce, Extranet, Decision Support System and Automated Manufacturing.

Table 7. Most common technologies $(n=38)$

Technologies listed in order of most common to least common

Rating scale: \% of the group using the technology in decreasing order of industry use.

\begin{tabular}{|c|l|c|l|c|l|}
\hline \multicolumn{2}{|c|}{ Not practised } & Internally only & \multicolumn{2}{|l|}{ Internally and with others } \\
Rating & Description & Rating & Description & Rating & Description \\
\hline $85 \%$ & Internet & $100 \%$ & Internet & $100 \%$ & Internet \\
\hline $71 \%$ & Intranet & $59 \%$ & Intranet & $77 \%$ & Data Management System \\
$42 \%$ & Data Management System & $54 \%$ & Data Management System & $55 \%$ & Intranet \\
$28 \%$ & E-Commerce & $31 \%$ & Data Warehousing & $44 \%$ & Data Warehousing \\
$14 \%$ & Data Warehousing & $31 \%$ & Automated Manufacturing & $33 \%$ & KM Software \\
\hline $14 \%$ & KM Software & $22 \%$ & E-Commerce & $22 \%$ & E-Commerce \\
\hline $14 \%$ & Extranet & $18 \%$ & KM Software & $11 \%$ & Extranet \\
\hline $14 \%$ & Decision Support System & $9 \%$ & Decision Support System & $11 \%$ & Decision Support System \\
\hline $14 \%$ & Automated Manufacturing & $9 \%$ & Groupware & $11 \%$ & Automated Manufacturing \\
\hline
\end{tabular}


The mean scores for Technology reveal that the information systems (IS) of most automotive OEMs are not linked to those of either their automotive OEM customers nor to other automotive OEMs and this indicates low levels of collaboration and networking among these companies (Table 8). Another point of interest portrayed by the descriptive statistics is that the IS of most companies are not accessible to all employees and indicates that knowledge, specifically tacit knowledge, is not being captured throughout these organizations and that valuable lessons learned may be lost, leading to repeated mistakes or "reinventing the wheel".

Table 8. Mean scores for technology $(n=38)$

\begin{tabular}{|l|c|}
\hline Rating statements & Mean \\
\hline $\begin{array}{l}\text { a) Information which is stored in the company information system is managed to } \\
\text { ensure validity, reliability and that information is up to date. }\end{array}$ & 3.8 \\
\hline $\begin{array}{l}\text { b) Our organization's information technology system is linked to that of our } \\
\text { automotive Original Equipment Manufacturer (OEM) customers. }\end{array}$ & 3.1 \\
\hline $\begin{array}{l}\text { c) Our organization's information technology system is linked to that of other } \\
\text { Automotive Component Suppliers. }\end{array}$ & 2.5 \\
\hline $\begin{array}{l}\text { d) The organizational information system is accessible throughout the company to all } \\
\text { employees. }\end{array}$ & 2.9 \\
\hline $\begin{array}{l}\text { e) Our organization's information technology system provides reports on its usage and } \\
\text { performance to management staff. }\end{array}$ & 3.5 \\
\hline $\begin{array}{l}\text { f) Our organization's information and communications technology system has } \\
\text { flexibility to meet future changes in requirements. }\end{array}$ & 3.5 \\
\hline $\begin{array}{l}\text { g) Security features in our organizational information system ensure that critical } \\
\text { information is not compromised and leaked to external sources. }\end{array}$ & 4.0 \\
\hline
\end{tabular}

No reliable Cronbach's alpha could be established for Technology as the measuring statements were varied and measured various aspects of Technology within the organization and did not correlate well with each other. However, the measuring statements were positively related to the importance of Technology to KM at the organization where low mean scores (below 3) would indicate low importance of Technology and high mean scores (above 3) would indicate high importance of Technology to KM at the organization. The descriptive statistics for Question 13 yielded relatively high mean scores, indicating a significantly high level of importance for Technology to KM at the organization. Analysing the mean scores for Technology across the levels of KMS complexity, however, produced no trend of increase in mean score with an increase in KMS complexity as established with the previous two variables Leadership and Organization.

The significance of the variable Technology in relation to the level of KMS complexity is shown (Table 9). The p-values obtained from the ANOVA test were all above the cut-off of $0.05(95 \%)$ and is an indication of non-significance for Technology in relation to the level of complexity of the KMS. The Null Hypothesis $\left(\mathrm{H}_{\mathrm{O} 3}\right)$ is therefore not rejected, stating that, "There is no relationship between Technology and the level of complexity of the knowledge management system".

The eta-squared values indicate that although the Null Hypothesis has not been rejected, the relationship between Technology and the level of complexity of the KMS, as measured by the differences in mean scores from the ANOVA test, is still indicated as being of Medium practical significance or importance in three cases (13c, $13 \mathrm{f}$ and $13 \mathrm{~g})$. 
Table 9. Significance of technology $(n=38)$

\begin{tabular}{|c|c|c|c|c|}
\hline Question 13 & P-value & $\begin{array}{l}\text { Statistical } \\
\text { significance }\end{array}$ & $\begin{array}{c}\text { Eta- } \\
\text { squared }\end{array}$ & $\begin{array}{l}\text { Practical } \\
\text { significance }\end{array}$ \\
\hline $\begin{array}{l}\text { a) Information which is stored in the company } \\
\text { information system is managed to ensure } \\
\text { validity, reliability and that information is up } \\
\text { to date. }\end{array}$ & 0.54 & $\begin{array}{l}\text { Not } \\
\text { significant }\end{array}$ & 0.034 & Small \\
\hline $\begin{array}{l}\text { b) Our organization's information technology } \\
\text { system is linked to that of our automotive } \\
\text { Original Equipment Manufacturer (OEM) } \\
\text { customers. }\end{array}$ & 0.68 & $\begin{array}{l}\text { Not } \\
\text { significant }\end{array}$ & 0.022 & Small \\
\hline $\begin{array}{l}\text { c) Our organization's information technology } \\
\text { system is linked to that of other Automotive } \\
\text { Component Suppliers. }\end{array}$ & 0.49 & $\begin{array}{l}\text { Not } \\
\text { significant }\end{array}$ & 0.040 & Medium \\
\hline $\begin{array}{l}\text { d) The organizational information system is ac- } \\
\text { cessible throughout the company to all em- } \\
\text { ployees. }\end{array}$ & 0.75 & $\begin{array}{l}\text { Not } \\
\text { significant }\end{array}$ & 0.017 & Small \\
\hline $\begin{array}{l}\text { e) Our organization's information technology } \\
\text { system provides reports on its usage and } \\
\text { performance to management staff. }\end{array}$ & 0.96 & $\begin{array}{l}\text { Not } \\
\text { significant }\end{array}$ & 0.002 & Small \\
\hline $\begin{array}{l}\text { f) Our organization's information and commu- } \\
\text { nications technology system has flexibility to } \\
\text { meet future changes in requirements. }\end{array}$ & 0.53 & $\begin{array}{l}\text { Not } \\
\text { significant }\end{array}$ & 0.036 & Medium \\
\hline $\begin{array}{l}\text { g) Security features in our organizational infor- } \\
\text { mation system ensure that critical infor- } \\
\text { mation is not compromised and leaked to ex- } \\
\text { ternal sources. }\end{array}$ & 0.41 & $\begin{array}{l}\text { Not } \\
\text { significant }\end{array}$ & 0.050 & Medium \\
\hline
\end{tabular}

\section{LEARNING}

The Cronbach's alpha for this construct has been calculated as 0.94 , which is above the cut-off value of 0.7 and indicates that this construct is highly reliable. Relatively high mean values were identified for the mean scores for Learning, indicating that Learning is perceived by respondents as being of high importance to practising KM in their organization (Table 10).

Table 10. Mean Scores for Learning $(n=38)$

\begin{tabular}{|l|c|}
\hline Rating statements & Mean \\
\hline a) Improving the company's competitive advantage & 4.4 \\
\hline b) Improving customer satisfaction & 4.4 \\
\hline c) Introducing innovations & 4 \\
\hline d) Inventory reductions & 3.6 \\
\hline e) Reduction of waste & 3.9 \\
\hline f) Employee training and development & 4.1 \\
\hline g) Cost reduction & 4.1 \\
\hline
\end{tabular}


The Application of a KM Framework to Automotive OEMs

\begin{tabular}{|l|c|}
\hline Rating statements & Mean \\
\hline h) Revenue growth & 4.2 \\
\hline i) Better decision-making & 3.9 \\
\hline j) Faster response to key business issues & 4 \\
\hline k) Improving quality & 4.3 \\
\hline l) Reducing throughput and delivery time & 4 \\
\hline m) Improving worker efficiency or productivity & 4 \\
\hline n) Prevented duplicate research and development & 3.7 \\
\hline o) Develop new measures and metrics for processes & 3.7 \\
\hline
\end{tabular}

No incrementally increasing trend is present across the KMS complexity levels in Figure 7, indicating that the importance of Learning does not increase with an increase in the complexity of the KMS.

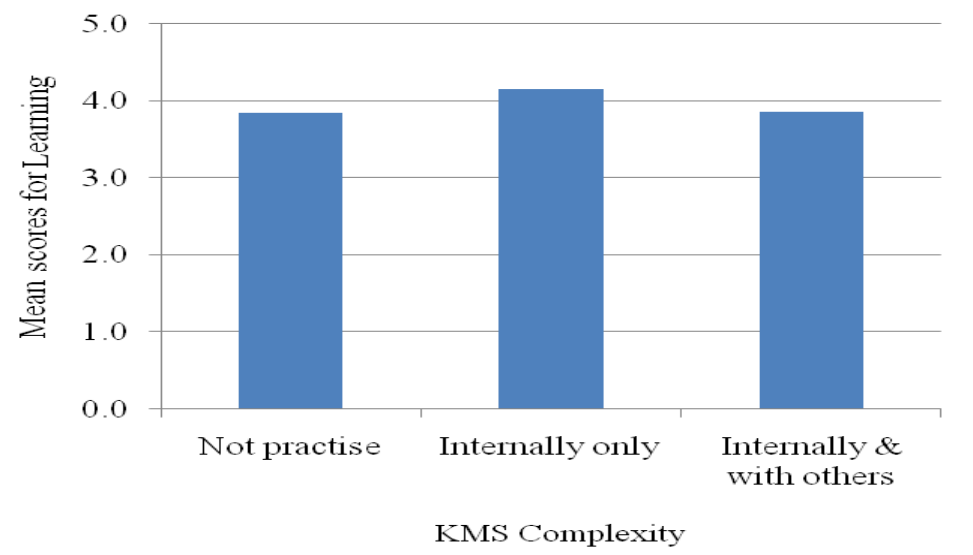

Figure 7. Importance of Learning $(n=38)$

An ANOVA was performed to test whether the Learning mean values for the three groups differ significantly. A p-value of 0.39 was obtained, indicating that the Null hypothesis $\left(\mathrm{H}_{\mathrm{O} 4}\right)$ has not been rejected, which states: “The three Learning means are equal'. Equivalently, this hypothesis states that "There is no relationship between Learning and the level of complexity of the knowledge management system". Calculating the effect size measure, eta-squared for this variable, a value of 0.052 was obtained, indicating that although the relationship is not statistically significant, it has some practical importance since an eta-squared value of 0.052 can be interpreted as Medium.

\section{DISCUSSION OF RESULTS}

Automotive OEMs generally have lower levels of resources at their disposal compared to those of Large and Extra-Large OEM organizations. This reflects the low level of knowledge sharing between organizations encountered in this study. The status of $\mathrm{KM}$ at the level of $1^{\text {st }}$ tier automotive OEMs reveals that there is a great need for improved KM in this industry. OEMs who realise the benefits of $\mathrm{KM}$ and react proactively to establish KM at their companies by developing organizational and technological infrastructure will place themselves in a favourable position to collaborate with others, at their level, in the supply chain and with their customers. These actions would improve their learning capability and create a competitive advantage over rivals in their market and afford them the ability to exploit more opportunities in the market compared to rivals with lesser KM capability (Heisig et al., 2016; Keshavarz et al., 2015; Wilson \& Campbell, 2016). The need for a mediating company such as 
Collaborative Exchange is essential in an OEM-supplier relationship where the IS of OEMs are more advanced than their suppliers and the suppliers are all using IS from various vendors.

It would be of great benefit to the automotive industry if NAACAM, acting as a central body, could drive and co-ordinate the creation of an industry standard for KM, at the level of $1^{\text {st }}$ tier suppliers, by means of benchmarking. The maturity of the OEM market, viability of the component supply industry within the Eastern Cape Province and the existence of various provincial business opportunities in the automotive component cluster indicates that opportunities exist in the Eastern Cape Province for collaboration between the IDZs of Coega and East London, with NAACAM.

The mean values for the Four Pillars, obtained from the results of the questionnaire indicate that these pillars are considered important for KM, regardless of the level of KMS complexity. The George Washington University's Four Pillar Framework covers a wide range of aspects which KM practitioners must consider when establishing a KMS. The ability to establish relationships between CSFs and the four pillars is essential to address the management dilemma and identify the areas where attention should be focused when the organization's KM issues are addressed.

The positive impact of KM in supplier relations within the automotive industry has been highlighted in literature (Sawant et al., 2015). The model presented in this study (Figure 2), $\mathrm{HO}_{1}$ was rejected, indicating that there is a relationship between Leadership and the level of complexity of the knowledge management system. Leadership has a large practical significance and management must identify knowledge critical to the business. Managers must align the KM strategy with the business strategy to achieve improved efficiency and profitability (Lopez-Nicolas \& Merono-Cerdan, 2011). $\mathrm{HO}_{2}, \mathrm{HO}_{3}$ and $\mathrm{HO}_{4}$ were not rejected, however the practical significance of Organization highlighted the importance of engaging all key stakeholders, the development of an inter-organizational process model and measurement programme. The high mean scores for Technology indicated the importance of technology to KM at all organizations. The high mean scores for Learning indicated that all respondents considered learning as highly important in their organizations.

The results further indicate that organizations, where reduced tenure in a current position is coupled with extended employment within the company, may be using career planning and job rotation to prepare candidates for senior positions within the organization. These employee retention strategies tend to retain tacit knowledge within the organization and reinforce culture, norms and values. The questionnaire further indicates that Learning within the organization supports the literature (Juceviciene \& Burksiene, 2009), where learning occurs at three levels within the organization namely, Individual, Group and Organization.

\section{CONCLUSIONS AND RECOMMENDATIONS}

Hahn and Subramani (2000) advocate a low-tech, bottom-up approach for the development of a KMS, by building on existing organizational or technological infrastructure. This is of interest to small and medium sized companies where resources are limited. Once an environment has been established, which is conducive to KM, the KM Aspects as illustrated in the applied KM framework (Table 3) must be established and may be periodically evaluated using the applied KM framework to establish the gaps in the company's KM practice.

The following recommendations are proposed to address the four pillars of the George Washington University's Four Pillar Framework:

\section{Leadership:}

- Develop a strategic vision, goals and KM strategy which is aligned with business goals and objectives; 
The Application of a KM Framework to Automotive OEMs

- Pursue employee buy-in and staff empowerment to reduce dependency and promote initiative by providing training and development and ensuring availability of the necessary resources; and

- Promote an open, encouraging and supportive culture.

\section{Organization:}

- Ensure flexibility of the organizational and technological infrastructure to meet changes in market demand; and

- Establish formal and informal networks along which knowledge can flow.

\section{Technology:}

- Ensure that the system is managed to ensure the validity and reliability of information and that information is up to date; and

- Ensure controlled accessibility to the organizational information system throughout the organization.

\section{Learning:}

- Promote employee training and development; and

- Promote Communities of Practice and cross-functional teams.

This research paper has presented an application of a KM framework at the level of $1{ }^{\text {st }}$ tier component suppliers. The use of this framework has successfully described the status of KM in the automotive industry. This study could be extended by investigating a methodology that includes KMS best practice and tools. The approach of using a KM framework does not present the practitioner with a methodology on how specific companies should implement and manage KM at their company. The identification of a methodology for KM implementation and management is beyond the scope of this study but presents the opportunity for future study. It is recommended that this study be repeated on a national and international level to provide a larger sample and an indication of KM practice within the entire automotive industry.

\section{REFERENCES}

Baloh, P., \& Desouza, K. C. (2009). Towards knowledge needs-technology fit model for knowledge management systems. Proceedings of the 4th International Conference on Design Science Research in Information Systems and Technology, Philadelphia, Pennsylvania, Article No. 20. https://doi.org/10.1145/1555619.1555646

Becerra-Fernandez, I., \& Sabherwal, R. (2015). Knowledge management: Systems and processes (1st ed.). New York: Taylor \& Francis.

Calabrese, F. A., \& Orlando, C. Y. (2006). Knowledge organizations in the twenty-first century: deriving a 12 step process to create and implement a comprehensive knowledge management system. Journal of Information and Knowledge Management Systems, 36(3), 238-254.

Calitz, A. P., \& Calitz, M. B. (2002). The design and implementation of a cost-effective knowledge management system - A South African case study. The 14th Annual Conference of the South African Institute of Management Scientists (SAIMS), Johannesburg.

Collis, J., \& Hussey, R. (2009). Business research: A practical guide for undergraduate and postgraduate students (3 ${ }^{\text {rd }}$ ed.). Basingstoke, UK: Palgrave Macmillan UK, $3 r d, 420$.

ECDC. (2011). Automotives and components. Retrieved from http://www.ecdc.co.za/opportunities/manufacturing

Ferreira, F., Faria, J., Azevedo, A., \& Marques, A. L. (2016). Product lifecycle management in knowledge intensive collaborative environments: An application to automotive industry. International Journal of Information Management, 37(1), 1474-1487. https://doi.org/10.1016/i.ijinfomgt.2016.05.006 
Gifford, D. (2015). Why auto suppliers need to confront their brain drain. Retrieved from http://www.autonews.com/article/20151229/BLOG06/151229939/why-auto-suppliers-need-toconfront-their-brain-drain

Hahn, J., \& Subramani, M. R. (2000). A framework of knowledge management systems: Issues and challenges for theory and practice. Proceeding ICIS '00 Proceedings of the Twenty First International Conference on Information Systems, Brisbane, Australia, 302-312. Retrieved from http://citeseerx.ist.psu.edu

Heisig, P. (2009). Harmonisation of knowledge management: Comparing $160 \mathrm{KM}$ frameworks around the globe. Journal of Knowledge Management, 13(4), 4-31. https://doi.org/10.1108/13673270910971798

Heisig, P., Suraj, O. A., Kianto, A., Kemboi, C., Arrau, G. P., \& Easa, N. F. (2016). Knowledge management and business performance: Global experts' views on future research needs. Journal of Knowledge Management, 20(6), 1169-1198. https://doi.org/10.1108/JKM-12-2015-0521

Holsapple, C. W., \& Joshi, K. D. (1999). Description and analysis of existing knowledge management frameworks. Proceedings of the 32nd Hawaii International Conference on System Sciences, Hawaii. https://doi.org/10.1109/HICSS.1999.772796

Ihantola, E.-M., \& Kihn, L.-A. (2011). Threats to validity and reliability in mixed methods accounting research. Qualitative Research in Accounting \& Management, 8(1), 39-58. https://doi.org/10.1108/11766091111124694

Juceviciene, P., \& Burksiene, V. (2009). A model of organizational learning for solution of problems of sustainable development: Changes in social and business environments. Proceedings of the $3 \mathrm{rd}$ International Conference, Lithuania, 167-174.

Keshavarz, S., Heydari, M., \& Farsijani, H. (2015). The strategic factors of knowledge management success in achieving organizational agility on the model (APQC) (Case study: Automotive-related companies). European Online Journal of Natural and Social Sciences, 4(1), 2309-2319.

Kinicki, A., \& Kreitner, R. (2008). Organizational behavior: Key concepts, skills \& best practices (3 ${ }^{\text {rd }}$ ed.). Taipei: McGraw-Hill Irwin.

Kumar, R. (2011). Research methodology: A step-by-step guide for beginners. London, UK: Sage.

Leedy, P. D., \& Omrod, J. E. (2010). Practical research: Planning and design (9th ed). New Jersey: Pearson.

Li, C. (2012). Knowledge stickiness in the buyer-supplier knowledge transfer process: The moderating effects of learning capability and social embeddedness. Expert Systems with Applications, 39(5), 5396-5408. https://doi.org/10.1016/j.eswa.2011.11.045

Liebowitz, J. (1999). The new star in organizations: The chief knowledge officer and the knowledge audit function. Proceedings of the 1999 ACM SIGCPR Conference on Computer Personnel Research, New York. https://doi.org/10.1145/299513.299604

Lopez-Nicolas, C., \& Merono-Cerdan, A. L. (2011). Strategic knowledge management, innovation and performance. International Journal of Information Management, 31, 502-509. https://doi.org/10.1016/i.iiinfomgt.2011.02.003

Magnier-Watanabe, R. (2011). Getting ready for kaizen: organizational and knowledge management enablers. VINE: The Journal of Information and Knowledge Management Systems, 41(4), 428-448. https://doi.org/10.1108/03055721111188520

Magnier-Watanabe, R., \& Senoo, D. (2008). Organizational characteristics as prescriptive factors of knowledge management initiatives. Journal of Knowledge Management, 12(1), 21-36. https://doi.org/10.1108/13673270810852368

Mar, A. (2013). 14 principles of knowledge management. Retrieved from https://management.simplicable.com/management/new/14-principles-of-knowledge-management

Maree, K. (Ed.) (2012). First steps in research. Pretoria: Van Schaik Publishers.

Moore, F. (2012). Identity, knowledge and strategy in the UK subsidiary of an Anglo-German automobile manufacturer. International Business Review, 21(2), 281-292. https://doi.org/10.1016/j.ibusrev.2011.03.003 
The Application of a KM Framework to Automotive OEMs

NAACAM. (2011). National Association of Automotive Component and Allied Manufacturers (NAACAM). Retrieved from http://www.naacam.co.za/site/default.asp

NAAMSA. (2017). Naamsa media release. Retrieved from http://www.naamsa.co.za/flash/press.html

Nunnally, J. C. (1978). Psychometric theory. New York: McGraw Hill.

OICA. (2011). A growth industry. Retrieved from http://oica.net/category/economic-contributions/

Ozlen, K., Handzic, M., \& Durmic, N. (2014). Empirical study of KMS impact on decision support. Eurasian Journal of Business and Economics, 7(13), 133-144.

Piderit, R. (2007). Knowledge management in multinational automotive suppliers: An investigation into the use of information systems. Retrieved from http://ufh.netd.ac.za/jspui/bitstream/10353/94/1/Piderit\%20thesis.pdf

Sajeva, S., \& Jucevicius, R. (2010). Determination of essential knowledge management system components and their parameters. Social Sciences/Socialiniai Mokslai, 1(67), 80-90.

Sawant, H. D., Teli, S. N., \& Gaikwad, L. M. (2015). Supplier-oriented knowledge management in the automobile industry. International Journal of Research in Aeronautical and Mechanical Engineering, 3(2), 36-46.

Scotiabank. (2017). Global auto report. Retrieved from http://www.gbm.scotiabank.com/English/bns_econ/bns_auto.pdf

Skyrme, D. J. (1997). From information management to knowledge management: Are you prepared? Retrieved from http://www.skyrme.com/pubs/on97full.htm

Stankosky, M. A. (2005). Advances in knowledge management: University research toward an academic discipline. Retrieved from http://v5.books.elsevier.com/bookscat/samples/9780750678780/9780750678780.PDF

Stankosky, M. F., Calabrese, F., \& Baldanza, C. (2003). A systems approach to engineering a knowledge management system. Washington, DC: Management Concepts Press.

Steyn, H. S. (2000). Practical significance of the difference in means. S.A. Tydskrif vir Bedryfsielkunde, 26(3), 1-3. https://doi.org/10.4102/sajip.v26i3.711

Sturgeon, T. J., \& Van Biesebroeck, J. (2010). Effects of the crisis on the automotive industry in developing countries: A global value chain perspective. Retrieved from

http://unstats.un.org/unsd/trade/s_geneva2011/refdocs/RDs/Automotive\%20Industry\%20and\%20Cris is \%20(Sturgeon \%20-\%20Jun\%202010).pdf

von Hippel, E. (1994). Sticky information and the locus of problem solving: Implications for innovation. Management Science, 40, 429-439. https://doi.org/10.1287/mnsc.40.4.429

Wilson, J. P., \& Campbell, L. (2016). Developing a knowledge management policy for ISO 9001: 2015. Journal of Knowledge Management, 20(4), 829-844. https://doi.org/10.1108/JKM-11-2015-0472

Zikmund, W. (2003). Business research methods (7th ed.). Mason: Thomson/South-Western.

\section{APPENDIX: QUESTIONNAIRE}

\section{INTRODUCTION}

The information obtained from this questionnaire will be treated with strict confidentiality, will not be used for any other purpose other than in writing the research dissertation for academic purposes only and will be presented in anonymous or aggregated fashion. Your co-operation to participate in this interview is greatly appreciated.

Benefits from participating:

You can indicate at the end of the questionnaire if you want a summary of the results. This provides you with an exclusive overview of the status of knowledge management in the Eastern Cape Province. 
When answering, you will automatically review the problems involved intensively, perhaps even receive new stimuli.

\section{QUESTIONNAIRE INSTRUCTIONS}

- Please indicate your answer by making an " $\mathrm{x}$ " or a tick in the appropriate box or by writing your answer in the space provided;

- Please answer the questions as honestly as possible;

- Please answer ALL the questions in this questionnaire.

\section{DEFINITIONS:}

Knowledge Management: Is the precise process of creating, collecting, storing and sharing organizational knowledge for use by employees within the organization to improve productivity and efficiency.

Knowledge Management Initiative: Any practice or policy that aims to encourage the creation, sharing and use of knowledge to realise an advantage for the organization.

Formal social networks: Formally established lines of reporting and formal communication within the company.

\section{ABBREVIATIONS:}

OEM: Original Equipment Manufacturer

KM: Knowledge Management

ACS: Automotive Component Supplier

\section{SECTION A-BACKGROUND INFO}

1. Name of your organization:

2. What is your current position / job title?

Please mark your choice with an " $\mathrm{X}$ " in the appropriate box:

3. How long have you been in this position?

0-5 years [ ] 6-10 years [ ] 11-15 years [ ] 16-20 years [ ] > 20years [ ]

4. How long have you been employed by your company?

0-4 years [ ] 5-9 years [ ] 10-14 years [ ] 15-20 years [ ] > 20years [ ]

5. Please indicate the approximate number of employees of the organization where you are employed at present:
$1-50[$ ]
$51-250[$ ]
$251-500[$ ]
$501-1000[$
$>1000[$ ]

6. Please select one of the following:

a) [ ] Our organization does not practice knowledge management; 
The Application of a KM Framework to Automotive OEMs

b) [ ] Our organization practices knowledge management internally only;

c) [ ] Our organization practices knowledge management internally as well as with Original Equipment Manufacturer (OEM) customers;

d) [ ] Our organization practices knowledge management internally as well as with other Automotive Component Suppliers.

e) [ ] Our organization practices knowledge management internally, with OEM customers and with other Automotive Suppliers

\section{SECTION B - LEADERSHIP}

7. Please rate the statements below by using the following scale:

1 - Strongly Disagree; 2 - Disagree; 3 - Neither Agree Nor Disagree;

4 - Agree; 5 - Strongly Agree

(indicate your selection by marking the appropriate box)

\begin{tabular}{|c|c|c|c|c|c|c|}
\hline & & 1 & 2 & 3 & 4 & 5 \\
\hline a) & $\begin{array}{l}\text { Senior management is usually able to provide sufficient resources as re- } \\
\text { quired for the implementation of various projects or initiatives. }\end{array}$ & & & & & \\
\hline b) & $\begin{array}{l}\text { Management usually involves line staff to establish their needs and get } \\
\text { their buy-in when implementing projects or initiatives. }\end{array}$ & & & & & \\
\hline c) & $\begin{array}{l}\text { Senior or experienced personnel are valued for their knowledge and ex- } \\
\text { pertise. }\end{array}$ & & & & & \\
\hline d) & $\begin{array}{l}\text { A strategic vision and goals for knowledge management has been estab- } \\
\text { lished by senior management. }\end{array}$ & & & & & \\
\hline e) & $\begin{array}{l}\text { Knowledge management is seen as an important practice at our compa- } \\
\text { ny. }\end{array}$ & & & & & \\
\hline f) & Our basic values \& purpose emphasise the sharing of knowledge. & & & & & \\
\hline g) & We have an open, encouraging \& supportive culture. & & & & & \\
\hline h) & $\begin{array}{l}\text { Our company has policies and programmes intended to improve worker } \\
\text { retention. }\end{array}$ & & & & & \\
\hline i) & Our company uses strategic partnerships to acquire knowledge. & & & & & \\
\hline j) & Our company is good at the capture and use of knowledge. & & & & & \\
\hline k) & $\begin{array}{l}\text { Management increases efficiency by using knowledge to improve general } \\
\text { productivity. }\end{array}$ & & & & & \\
\hline 1) & $\begin{array}{l}\text { Management identifies and protects strategic knowledge present within } \\
\text { the company. }\end{array}$ & & & & & \\
\hline $\mathrm{m})$ & $\begin{array}{l}\text { Our organization is good at transferring and sharing of knowledge with } \\
\text { clients or customers. }\end{array}$ & & & & & \\
\hline & $\begin{array}{l}\text { Capturing of critical know-how (e.g. project information etc.) forms part } \\
\text { of our daily routine. }\end{array}$ & & & & & \\
\hline
\end{tabular}

8. Please note your comments on management and leadership, with regard to knowledge management at your company: 


\section{SECTION C - ORGANIZATION}

9. Please rate the statements below by using the following scale:

1 - Strongly Disagree; 2 - Disagree; 3 - Neither Agree Nor Disagree;

4 - Agree; 5 - Strongly Agree

(indicate your selection by marking the appropriate box)

\begin{tabular}{|c|c|c|c|c|c|c|}
\hline & & 1 & 2 & 3 & 4 & 5 \\
\hline a) & Our organizational management structure is decentralised. & & & & & \\
\hline b) & $\begin{array}{l}\text { Our organizational management hierarchy has many levels of manage- } \\
\text { ment. }\end{array}$ & & & & & \\
\hline c) & $\begin{array}{l}\text { Senior management is always able to implement changes in the techno- } \\
\text { logical infrastructure quickly to ensure the success of various projects or } \\
\text { initiatives. }\end{array}$ & & & & & \\
\hline d) & $\begin{array}{l}\text { Our organization is flexible and can adapt quickly to meet changes in } \\
\text { demand from the market. }\end{array}$ & & & & & \\
\hline e) & $\begin{array}{l}\text { The organizational structure and interaction of various departments cre- } \\
\text { ate formal social networks through which knowledge flows in our organ- } \\
\text { ization. }\end{array}$ & & & & & \\
\hline f) & $\begin{array}{l}\text { Informal organizational relationships between employees create informal } \\
\text { social networks through which knowledge flows in our organization. }\end{array}$ & & & & & \\
\hline g) & $\begin{array}{l}\text { Formal interaction with our company's automotive Original Equipment } \\
\text { Manufacturer (OEM) customers create formal social networks which fa- } \\
\text { cilitate knowledge-sharing between our company and our automotive } \\
\text { OEM customers. }\end{array}$ & & & & & \\
\hline h) & $\begin{array}{l}\text { Informal inter-organizational relationships between employees (via } \\
\text { email, chat rooms etc.) create informal social networks which facilitate } \\
\text { knowledge-sharing between our organization and our automotive OEM } \\
\text { customers. }\end{array}$ & & & & & \\
\hline i) & $\begin{array}{l}\text { Formal interaction with other Automotive OEMs create formal social } \\
\text { networks which facilitate knowledge-sharing between our organization } \\
\text { and other ACS. }\end{array}$ & & & & & \\
\hline j) & $\begin{array}{l}\text { Informal inter-organizational relationships between employees (via } \\
\text { email, chat rooms etc.) create informal social networks which facilitate } \\
\text { knowledge-sharing between our organization and other ACS. }\end{array}$ & & & & & \\
\hline
\end{tabular}

10. Please note any other comments on your company's organizational structure with regard to knowledge management:

\section{SECTIOND - TECHNOLOGY}

11. Which technologies have your company implemented? (Please mark all that apply)
a) Internet
[ ]
b)
Data warehousing
c) Intranet
[ ]
d)
Knowledge management software
[ ]
e) Extranet
[ ]
f)
Decision support system
[ ]
g) Groupware
[ ] h)
Data management system
[] 
The Application of a KM Framework to Automotive OEMs

i) E-Commerce [ ] j) Automated Manufacturing

k) If any other, please specify:

12. What is the name of the inventory management system currently used by your company?

13. Please rate the statements below by using the following scale:

1 - Strongly Disagree; 2 - Disagree; 3 - Neither Agree Nor Disagree;

4 - Agree; 5 - Strongly Agree

(indicate your selection by marking the appropriate box)

\begin{tabular}{|c|c|c|c|c|c|c|}
\hline & & 1 & 2 & 3 & 4 & 5 \\
\hline a) & $\begin{array}{l}\text { Information which is stored in the company information system is man- } \\
\text { aged to ensure validity, reliability and that information is up to date. }\end{array}$ & & & & & \\
\hline b) & $\begin{array}{l}\text { Our organization's information technology system is linked to that of } \\
\text { our automotive Original Equipment Manufacturer (OEM) customers. }\end{array}$ & & & & & \\
\hline c) & $\begin{array}{l}\text { Our organization's information technology system is linked to that of } \\
\text { other Automotive Component Suppliers. }\end{array}$ & & & & & \\
\hline d) & $\begin{array}{l}\text { The organizational information system is accessible throughout the } \\
\text { company to all employees. }\end{array}$ & & & & & \\
\hline e) & $\begin{array}{l}\text { Our organization's information technology system provides reports on } \\
\text { its usage and performance to management staff. }\end{array}$ & & & & & \\
\hline f) & $\begin{array}{l}\text { Our organization's information and communications technology system } \\
\text { has flexibility to meet future changes in requirements. }\end{array}$ & & & & & \\
\hline g) & $\begin{array}{l}\text { Security features in our organizational information system ensure that } \\
\text { critical information is not compromised and leaked to external sources. }\end{array}$ & & & & & \\
\hline
\end{tabular}

14. What are the problems faced by your company in using IT for Knowledge Management?

(Please mark all that apply)

a) Lack of training.

b) System is too complicated.

c) Lack of identifying the proper IT tool

d) Lack of time to learn.

e) Lack of user uptake due to insufficient communication.

f) Every day use did not integrate into normal working practice.

g) Unsuccessful due to technical problems.

h) If any other, please specify:

15. Please note any other comments on your company's technological infrastructure with regard to knowledge management:

\section{SECTION E - LEARNING}

Please mark your choice with an " $\mathrm{X}$ " in the appropriate box (mark more than one box if applicable):

16. At our company, learning on an individual level is achieved by:

a) [ ] On the job training 
b) [ ] Formal training workshops

c) [ ] Company knowledge bases

d) [ ] On-line (i.e. through the company's intranet, internet or extranet)

e) [ ] Other

Please specify other:

17. Learning on a team or departmental level is achieved by:

a) [ ] On the job training

b) [ ] Formal training workshops

c) [ ] Company knowledge bases

d) [ ] On-line (i.e. through the company's intranet, internet or extranet)

e) [ ] Other

Please specify other:

18. Learning on an organizational level is achieved by:

a) [ ] Recording information in an organizational database

b) [ ] Recording information on the organization's intranet

c) [ ] Other

Please specify other:

19. Organizational learning is monitored at our organization through the use of:

a) [ ] Organizational training register

b) [ ] Other methods

Please specify other methods:

20. Does your company actively create and support "Communities of Practice (CoP's) in their organization?

(CoP: An informal, self-organising group of people in the organization, brought together by common interest who share expertise and solve problems together.)
a) Yes [ ]
b) No [ ]
c) Can't say [ ]

21. Please rate the significance of, retaining knowledge (i.e. learning) in your organization, with regard to the statements below by using the following scale:

1 - No significance; 2 - Low significance; 3 - Average significance;

4 - Above average significance; 5 - Extremely high significant

(indicate your selection by marking the appropriate box)

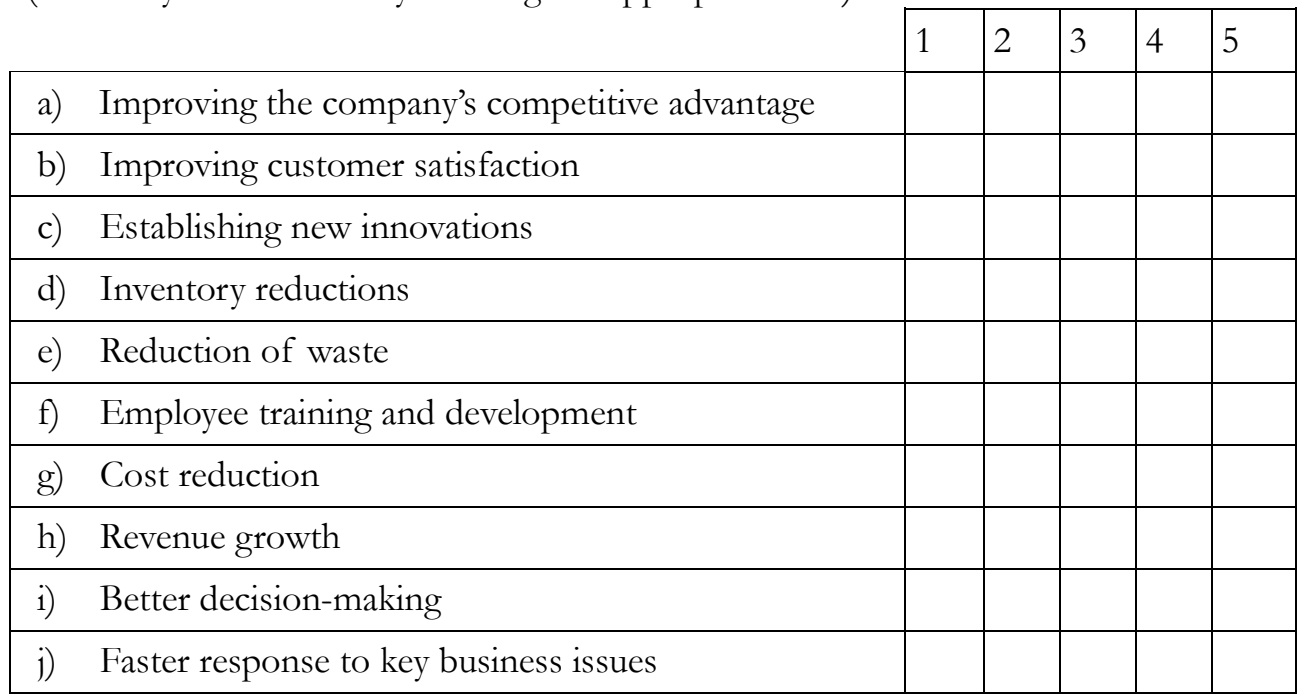


The Application of a KM Framework to Automotive OEMs

\begin{tabular}{|l|l|l|l|l|l|} 
k) Improving quality & & & & & \\
\hline l) Reducing throughput and delivery time & & & & & \\
\hline m) Improving worker efficiency or productivity & & & & & \\
\hline n) Prevented duplicate research and development & & & & & \\
\hline o) Develop new measures and metrics for processes & & & & & \\
\hline
\end{tabular}

22. Please note any other comments on your company's technological infrastructure with regard to knowledge management:

\section{SECTION F - CHALLENGES IN APPLYINGKNOWLEDGE MANAGEMENT}

Please mark your choice with an " $\mathrm{X}$ " in the appropriate box (mark more than one box if applicable):

23. What are the challenges currently experienced by your company?
a) [ ]
Lack of relevant information
b) $[$ ]
Information overload
c) [ ]
a) []
b) $[$ ]
c) []
Reinventing the wheel
Loss of crucial knowledge due to a key employee leaving the organization.
Poor sharing of knowledge in the organization.
If any other, please specify:

24. Please mention some of the benefits which your company could derive from implementing knowledge management.

25. Kindly indicate, in your opinion, how senior management can be motivated to introduce Knowledge Management practices.

26. Kindly indicate the steps, which an automotive component supplier should take for successfully implementing a Knowledge Management Programme. Also indicate the relative importance of IT in this context.

27. Does your company reward knowledge sharing with:
a. [ ] monetary incentives
b. [ ] non-monetary incentives
c. [ ] not applicable

28. Please briefly describe the knowledge management initiatives which are currently being pursued to facilitate knowledge-sharing between your company and your automotive OEM customers?

29. Please briefly describe the knowledge management initiatives which are currently being pursued to facilitate knowledge-sharing between your company and other automotive component suppliers?

\section{CONCLUSION}

30. Please mark one of the boxes below to indicate if you would like to receive a copy of the summarised results of this study:

$$
\text { Yes [ ] No [ ] }
$$

31. Do you have any additional comments you would like to add? Your opinion is most valued:

Thank-you for your participation. Your valuable contribution to this study is sincerely appreciated. 


\section{BIOGRAPHIES}

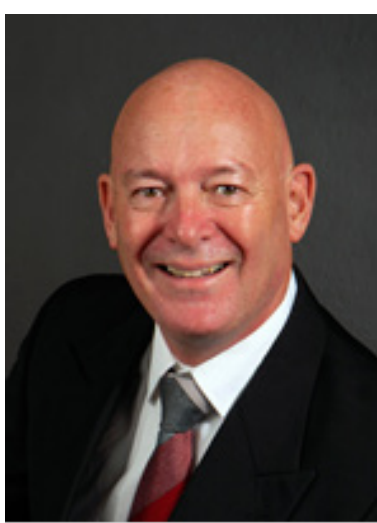

André Calitz is a Professor in the Department of Computing Sciences at the Nelson Mandela University (NMU) in Port Elizabeth. He has two doctorates, a PhD in Computer Science and a Doctorate in Business Administration (DBA) from the NMU Business School. He is a rated NRF researcher and has published extensively in local and international journals and conferences. He is the Chairman/President of the Southern African Computing Lecturers Association (SACLA) and Chairman of the South African Computing Accreditation Board (SACAB) and was awarded the Eastern Cape ICT Computer Person of the Year and is a Fellow of the Institute of IT Professionals of South Africa. His research interests include Industry 4.0 and the use of Big Data in Smart Factories and Smart Cities.

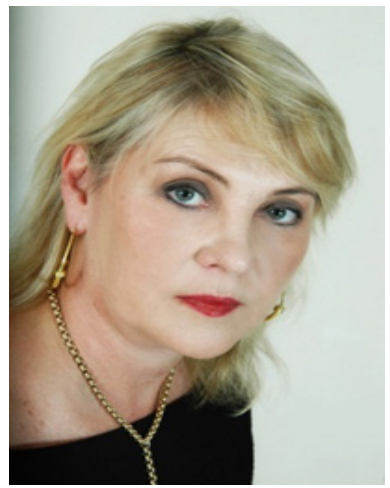

Margaret Cullen is a Professor of Entrepreneurship at the Nelson Mandela University Business School in Port Elizabeth, South Africa. She supervises MBA and DBA student research and has authored and coauthored numerous research articles. She heads up the Strategic Focus area of Entrepreneurship, Design Thinking and Innovation. In 2010, Prof. Cullen was the winner of the Business Women's Association's Business Women of the year in the Professional category (Eastern Cape). Professor Cullen also consults in the areas of experiential marketing, strategy, family business and entrepreneurship. She is passionate about making a difference through the correct delivery of entrepreneurial teaching. Her research interests include Smart cities and Happiness. 